\title{
Impact of Banking Risks on the Electronic Banking Services: A Comparative Study
}

\author{
Abdul-Hussein Jasim Mohammed ${ }^{1}$, Munaf Abdulkadhim Mohammed ${ }^{2}$, \\ Ahmed Hussein Ahmed ${ }^{1}$ \\ ${ }^{1}$ Faculty of Administration and Economics, University of Kerbala, Kerbala, Iraq \\ ${ }^{2}$ Basra Education Directorate, Basra, Iraq
}

\begin{abstract}
This paper aims to explore the impact of banking risk on electronic banking services in the Rafidain Bank and the Baghdad Bank. The study adopted the field survey method as a method of data collection and analysis. The sample included managers, their assistants, and the heads of departments who are at the decision-making site who were chosen intentionally, consisting of 43 people, including 25 from the Rafidain Bank and 18 from the Bank of Baghdad. A questionnaire was distributed to measure the study variables. The results show a significant impact of credit risk and liquidity risk on usability, benefits and cost reduction. Therefore, it is necessary to put in place mechanisms by the banks in question to help reduce risks, as these risks are the cause of many banking crises.
\end{abstract}

Keywords - Banking Risks, Electronic Banking Services, AL-Rafidain Bank, Baghdad Bank.

\section{Introduction}

The banking sector is exposed to many risks that could lead to its instability.

DOI: 10.18421/TEM102-22

https://doi.org/10.18421/TEM102-22

Corresponding author: Abdul-Hussein Jasim Mohammed, Faculty of Administration and Economics, University of Kerbala, Iraq.

Email: mabdulhusseinjasim@gmail.com

Received: 13 October 2020.

Revised: 11 March 2021.

Accepted: 20 March 2021.

Published: 27 May 2021.

(c))BY-NC-ND (C) 2021 Abdul-Hussein Jasim Mohammed, Munaf Abdulkadhim Mohammed \& Ahmed Hussein Ahmed; published by UIKTEN. This work is licensed under the Creative Commons Attribution-NonCommercialNoDerivs 4.0 License.

The article is published with Open Access at www.temjournal.com
The risk management has become the focus of attention of many regulatory and monetary authorities, in particular the Basel Committee for Banking Supervision, which has studied and analyzed the causes of banking crises that ravaged most of the countries of the world [1]. As a result, it has become imperative for those in charge of banking management to keep in mind special strategies to study the phenomenon of banking risks and to develop appropriate methods, procedures and methods for following up and facing these risks in order to reduce their negative effects. The banking activity does not work to avoid risks, but rather deal with them to reduce their impacts. The banking risks have become a cornerstone of the banking business, which is in the electronic banking services an integral part of its work. As a result of the transformations taking place in the Iraqi banking sector that helped the expansion and the entry of Arab and foreign banks to work in the Iraqi environment, this was reflected in the inability of the Iraqi banking institutions to manage the risks they are exposed to. Consequently, its impact on banking services in general and in particular electronic banking services has increased. The banking sector is one of the most exposed financial sectors due to the developments and changes that this sector is witnessing and facing [2]. The risks facing the banking sector have grown due to the rapid technological developments and the emergence of many contemporary financial instruments. These risks are an integral part of the work of any bank. The diversity in these risks and the difference in the degree of their impact on banks according to the different means and methods used in confronting them, the issue of banking risks has received wide attention from the banks 'departments to the effect of electronic banking services on them. Therefore, this study aims to show the impact of banking risks on electronic banking services in the Rafidain and Baghdad banks. 


\section{Literature Review}

\subsection{Banking Risks}

The risks associated with banking have varied and varied. These risks are threatening the core business of banks and restrict their ability to use their sources of funds. Accordingly, the banks have created the need to set goals and prepare various strategies to define these risks, measure them, and define the factors that affect them. Banking crises have aroused the interest of bankers at the international banking level [3]. The succession of financial and banking crises between countries is considered to be reliable, undermining financial globalization and refuting the views of those countries that support it [4]. The succession of financial and banking crises between the countries is seen as credible, undermining financial globalization and refuting the views of those countries that favor it. That is why the Basel Committee issued a number of guidelines for managing each type of risk, such as capital risk, credit risk and liquidity risk, to ensure sound banking risk management. Therefore, banks in general face a wide range of risks in the course of their banking operations that require bank managers to understand their nature and ensure their appreciation and proper behavior towards them in order to remain in the field of competition [5]. Banking risk is defined as the irregularity of the returns and the fluctuation of its value in relation to the capital invested, which constitutes the risk element [6]. [7] define it as the potential for adverse and unexpected events to adversely affect the capital or returns of the bank. Risk management is the work to reduce or minimize the absolute level of risk. There are three main reasons driving the banking administration in this direction [8]:

$>$ The fluctuation of the return on assets is reflected in the fluctuation of the nominal value of shares, i.e. fluctuation in the wealth of owners. It is something that may lead them to demand a high return on capital that would lead to a high cost of money for banks.

$>$ The government represented by the central bank usually monitors the performance of banks to ensure that its profits are not subject to extreme fluctuations. Extreme volatility in returns would increase the risks faced by the parties concerned with banks.

$>$ The desire of banks to maintain the confidence they enjoy drives them to achieve stability in return. This may mean avoiding directing its financial resources to investments that involve a large amount of risk, even if the expected return from them is significant. [9] classify the risks in terms of the means to control them into:
- The risks that the bank does not wish to assume, in which case the bank transfers them to insurance companies and specialized financial institutions through the sale of credit facilities at risk.

- The risks that can be avoided. These are the risks associated with operational activities. It is controlled through the application of internal control methods and strictly following them such as weaknesses in security and protection systems, negligence in the implementation of tasks as stipulated in the work procedures, giving confidential information about the bank's customers, frequent accounting errors and damage or loss of important documents.

- Risks that can be managed or accepted in the risks resulting from a basic activity, but it cannot be transferred. The cost of transfer is greater than the cost of managing it, or because risk is an integral part of a profitable activity of the bank and can be compensated appropriately.

The bank risk management indicates that the bank is exposed to unexpected and unplanned losses in addition to fluctuating expected returns on a particular investment. In addition, bank risks may arise from multiple sources, including a lack of diversity or a lack of liquidity [10]. They believe that risks can be measured by two approaches, according to the Basel framework, namely:

1. Standard approach: The standard method used to measure risks is the simplest to calculate capital requirements especially in banks that do not perform complex activities. This approach includes a more accurate classification of risks, in addition to expanding the framework for taking mortgages to cover credit risks. It also identifies new ways to mitigate these risks, and thus reduce the capital burden.

2. The internal classification approach: It is considered one of the advanced methods for measuring risks. Banks that use this approach to measure and assess their risks meet the following minimum requirements (data accuracy, measurement systems, internal control and accuracy of the disclosure process). This approach relies on banks' self-assessments to measure risk components, or with the assistance of regulatory authorities, with a view to arriving at the weights of assets risk. Accordingly calculating the capital to be held, because it makes the capital requirements more in line with the degree of risk. Banks that have a credit portfolio with high quality collateral are exposed to less risk and need less capital and vice versa if they maintain a credit portfolio with low quality collateral. This gives some 
banks an incentive to develop their internal risk management systems. Banks that operate according to this approach rely on internal assessments to assess credit risk in a way that allows them to establish ratings related to the probability of default.

In order to determine and measure the bank risks, [11] indicate that capital risks reflecting insufficient capital to absorb losses that may arise and reach depositors' money and creditors. Credit risk represents the potential loss as a result of credit customers' refusing to pay or their inability to repay the debt in full and on time. Credit risk arises when banks give customers loans that are repayable at a specified time in the future and customers fail to meet their payment obligations when the loans are due [12]. Finally, liquidity risk represents the banks inability to pay financial obligations when they are due, in addition to their inability to meet their shortterm obligations. It is also the overall risk resulting from the sudden withdrawal of deposits and other obligations of the banks, which makes the banks compelled to sell their assets in a short period and at low prices to face the sudden withdrawal. Banking risks can be classified as: financial and non-financial risks:

\section{1- Financial risks}

A - Market risks: They expose the balance sheet items on or off the balance as a result of price fluctuations in the market, and include the risks arising from the fluctuation of interest rates and from the volatility of share prices in financial instruments classified within the trading portfolio and the risks resulting from the volatility of foreign exchange prices [13]. Foreign exchange risk is the risk that foreign currency selling and buying (exchange) prices will fluctuate against the national currency if the bank has assets denominated in foreign currencies [14].

B - Credit risk: Credit risk is the risk that it will result from credit clients refusing to pay or their inability to pay the debt in full and on time. Credit risk usually arises when the bank gives customers loans that are repayable at a specified time in the future and the customer fails to meet its payment obligations by the time, thus the loan is returned [15].

C - Liquidity Risks: Many economists link the banking system's shakes and the banks' budget structure. It is because once there is no time agreement between assets and liabilities; the bank exposes itself to the risk of liquidity. Thus, the liquidity risk can be defined as [16] the bank's inability to pay financial obligations when they are due and the bank's failure to meet its short-term obligations. This is the beginning of the occurrence of a deficit phenomenon that, if persistent, could lead to bankruptcy. Some people define it as: the risks resulting from the sudden withdrawal of deposits and other liabilities of the bank, which makes the bank obliged to sell its assets in a short period and at low prices to counter the sudden withdrawal [17]. It is also known as: Differences in net income and the market value of property rights resulting from difficulties facing the bank in obtaining cash at a reasonable cost, whether from selling assets or obtaining loans or new deposits.

D - Capital risk: The reason for this risk is due to insufficient capital to absorb losses that can occur and reach the funds of depositors and creditors [18].

\section{2- Non-financial risks:}

According to [19] and [20] the non- financial risks include the following:

A - Operating risks: The Basel Committee defined them as the risks of exposure to losses resulting from the failure or insufficiency of each of the following: internal operations - workers - systems in the bank - external events. The operating risks are related to the daily work of the bank and therefore they are very wide and renewed day by day with the continuation of work, including: embezzlement / bribery, bank theft, natural disasters, fraud (internal or external) error of the alcove employees exceeding the powers to trade in foreign currencies and securities failure in systems technology losses issues negligence in executing tasks giving confidential information about clients losing or damaging important documents.

B - Strategic risks: The strategy means the main path that the bank takes for itself to achieve its objectives in the short and long terms. That is, we can say that it is the risk resulting from the bank's taking wrong decisions, wrong implementation of decisions, or failure to make a decision in time, which may lead to losses or loss of alternative opportunities.

C - Legal risks: This type of risk arises from the bank's failure to comply with the standards and laws established by the regulatory authorities. This exposes the bank to penalties for violating these laws.

D - Reputation risk: the presence of a negative impression on the bank, which results from it. Consequently, losses in funding sources or transfer of customers to competing banks become the result of actions taken by employees or managers of the bank, or a result of failure to serve customers with the speed, accuracy, and required quality, which thus leads to a disturbance of confidence in the bank. Quantitative measures are difficult in practice to measure risks (strategic, legal, and reputation). However, the development of the general performance of the bank from year to year gives an indication of the bank's success in strategic planning 
and its commitment to legal procedures, its quality and reputation.

In the same context, there are five factors that influence their banking risks, which can be summarized below:

1) Legal changes: These changes are considered to support the peaceful credit management standards. The establishment of formal control over the risk centre reflects the type of standards that the banking administration is obliged to apply.

2) Volatility of external factors: The changes and fluctuations in interest rates and exchange rates greatly affect the institutions' budget. It may turn its profits into losses and affect the bank's treasury, because the bank is sensitive to changes in interest rates.

3) The bank's financial activities: such activities do not appear in the budget in the form of assets or liabilities, although they have a clear impact on bank returns and risks, and these activities are:

A. Activities that generate profits or expenses without owning assets or creating obligations, for example, the bank's work as a broker, where it gets paid to provide money to its applicants without granting loans or increasing deposits with it, or to obtain a wage in exchange for managing cash without the need for assets or arranging obligations

B. Contingent pledges or obligations: This means the bank's commitment to do a certain job in the future in return for a fee that it receives.

4) Competitive pressures: The competitive environment in which banks operate directly or indirectly affects the risk. Indeed, the banks prepare themselves to face competition.

5) Technological developments: The developments that occur in the field of information technology affect the overall process that includes determining the measurement and management of risks. Technology is one of the main factors that contribute to determining the advantages of competition between different institutions. The analysis and management of risks are based on information processing.

Consequently, the effectiveness and integrity of the bank's decisions depend on its ability to know the risks, determine their nature and adapt to them. This requires the bank to know the various main types of banking risks and to define their sources, so that the decision-maker can reach sound and objective decisions.

\subsection{Electronic Banking Services}

Banks play a leading role in developing the economies of countries through their various services that they provide to the public. With the start of the information revolution, the use of the Internet, and the increase in electronic commerce operations, banks have witnessed a qualitative transfer in banking services [21]. They has become a great need for a new type of unconventional banking service. These services are electronic banking services or the so-called electronic banking provided by electronic banks that exceed the normal performance pattern and do not adhere to a specific place or time. Electronic banking services refer to banking operations that are electronic, among which the Internet is one of the most important forms [22]. It also performs banking operations by electronic means through the use of information and communication technology, whether it comes to traditional or contemporary banking [23]. [24] show that electronic banking services represent the automatic delivery of traditional and contemporary banking services directly to customers through interactive electronic communication channels. According to this definition, the patterns of electronic banking services are numerous, but the most prominent are:

1. Account management services over the phone, as these services allow customers to easily manage their bank accounts such as balance inquiry and transfer between personal accounts.

2. Transfer services from one bank to another, which includes transferring, paying or withdrawing balances between banks through the various communication networks.

3. Online account statement services through which customers can obtain account statements at the time they want to monitor daily, monthly or annual movements through their e-mail.

4. ATM services that allow customers to service withdrawing money via a special card that is entered into the ATM in addition to monitoring the balances.

In order to determine and measure the electronic banking services, [25] and [26] identify three dimensions. The dimensions of electronic banking services include usability that clarifies the degree to which an individual believes that using a particular system will be effortless. While the benefit achieved indicates the degree to which an individual believes that the use of a particular system would enhance the performance of his function [27]. Finally, cost reduction is associated with the amount of time and money saved when using an innovative self-service. Electronic banking distinguishes itself by providing distinguished services over traditional banking services to meet the needs of the customer [28]. Electronic banking services have many advantages: 
1. The ability to reach a broader base of customers: The electronic banking is characterized by its ability to reach a broad base of customers without being restricted to a specific place or time, as it produces the possibility of requesting the service at any time and throughout the days of the week, which provides convenience to the customer, adding to confidentiality of transactions, which increases the confidence of customers

2. Providing integrated and new banking services: E-banking includes all traditional banking services, and besides it more advanced services through modern means that distinguish them from traditional performance such as:

A- Issuing electronic advertising bulletins on banking services;

B- Providing customers with a way to verify their balances with the bank;

C- Provide a way for customers to pay bills drawn on them electronically;

D- How to manage financial portfolios (from stocks and bonds) to customers;

E- How to transfer money between different customer accounts.

3. Reducing costs: One of the most important features of electronic banking is that the costs of providing the service are low compared to the traditional banking business. Hence, reducing costs and improving their quality are factors in attracting the customer. The results of the comparison between electronic and traditional banking work show that the cost of providing services in electronic channels decreases about six times in the traditional channels of banking work, and the percentage of savings in electronic banking transactions is estimated at $89 \%$ for online banking transactions, compared to it in traditional patterns.

4. The speed of completing banking business: Due to the expansion of modern technology and the speed with which it resulted in the completion of the banking business, it has become easier for the customer to contact the bank and implement procedures that end up in small parts of a minute with proper performance and high efficiency than if the customer is moved to the bank's headquarters to personally carry out the required activities.

5. Cards Services: Electronic banking provides distinguished services for businessmen, customers with a prestigious level, such as Samba Diamond and Gold services provided to a specific category of customers in the form of credit cards and a special discount.
On the other hand, [29] show the most important factors affecting electronic banking in the following:

1. Change in the customers' behaviour: The most common phenomena of change in the customers' behaviour are those that require acquiring knowledge of how to use the machine and deal with modern devices and bank cards, when requesting a quantity of money and depositing or transferring it. This means that customers should be directed to and taught how to use these technologies and deal with their mechanics. It is noticeable that there is a high desire among many bank customers to use electronic banking business techniques, which negatively affects the development of these services due to the limited users.

2. Competition: The competition factor is one of the strongest factors that drive banks to use the Internet as a means of communication through which banking services and products are provided to their clients and maintain and attract new clients. It is noted that competition in private banks is limited in relation to electronic banking due to its compliance with the laws of the central bank, which limits its movement and creativity in relation to electronic banking work.

3. Technological innovation: This aspect has a clear impact on the banking services market. The use of technology contributes to expanding resources and the ability of banks to compete in this upcoming industry. Due to the private banks being subject to the supervision of the central bank on the one hand, and the weakness of the human cadre with regard to electronic services and limited capabilities on the other hand, in addition to the current banks' reliance on importing technology and copies of external banking services, this led to the absence of the technological innovation factor in private banks.

4. Customer relations and quality: The main task of marketing lies in attracting the customer and the continuity of strengthening the relationship with him and collecting his overall satisfaction with banking services. The customer places the quality of service at the forefront of the required things. Depositing, withdrawing and transferring are all related to the quality component in terms of speed, accuracy and efficiency in work and the Internet provides this.

5. Deepening loyalty: Banks are always keen to consolidate and deepen the relationship between them and customers to create a kind of loyalty to the bank. Since the Internet works to increase the chances of a customer contacting a bank and obtaining his services and products within a wider circle of place and time, this leads to the consolidation of the relationship between them and the creation of a new type of loyalty. 


\section{Data and Methodology}

\subsection{Instrument}

This study uses the qualitative approach, and the research model attempts to explain the relationship between independent and dependent variables. To achieve the goals of the research a survey was conducted to collect data.

\subsection{Research Variables and Model}

Figure 1 illustrates a research model that shows the set of key variables for the current study. The figure includes the following variables:

\section{The independent variable}

Banking risk: the possibility of exposing the bank to unforeseen and unforeseen losses and / or fluctuating expected returns on a particular investment [11]. It was measured by capital risk, credit risk and liquidity risk.

\section{The dependent variable}

Electronic banking services: direct automatic delivery of new and traditional banking services to clients through interactive electronic communication channels [25]. It was measured by usability, benefits and cost reduction.

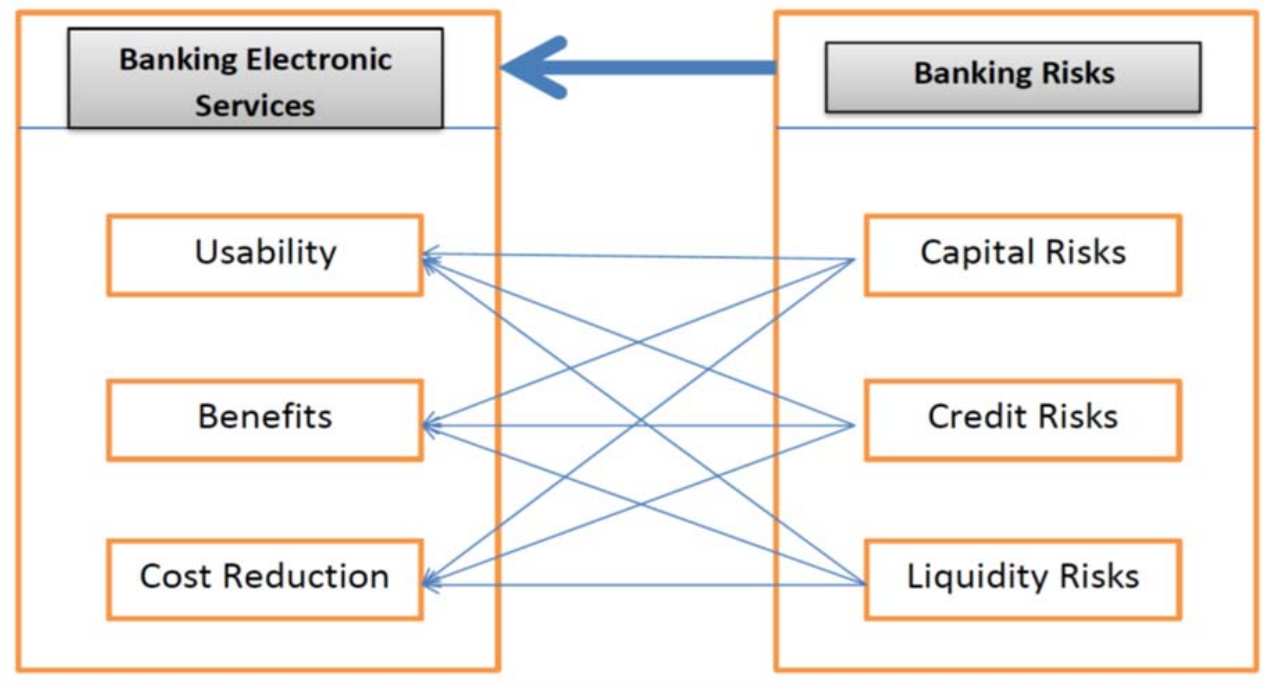

Figure 1. Research Model

Accordingly, the study hypotheses can be formulated as follows:

Ha1: There is a significant impact of the capital risks on the usability of electronic banking services in the Rafidain Bank and the Baghdad Bank.

$\mathrm{Ha} 2$ : There is a significant impact of capital risk on the benefit accrued from electronic banking services in Al-Rafidain Bank and Baghdad Bank.

Ha3: There is a significant impact of capital risk on cost reduction of electronic banking services in Rafidain Bank and Baghdad Bank.

$\mathrm{Hb} 1$ : There is a significant impact of credit risk on the usability of electronic banking services at the Rafidain Bank and the Baghdad Bank.

$\mathrm{Hb} 2$ : There is a significant impact of credit risk on the benefit accrued from electronic banking services in Rafidain Bank and Baghdad Bank.

$\mathrm{Hb} 3$ : There is a significant impact of credit risk on cost reduction of electronic banking services in Rafidain Bank and Baghdad Bank.

$\mathrm{Hc} 1$ : Liquidity risk affects the usability of electronic banking services in the Rafidain Bank and the Baghdad Bank.
Hc2: There is a significant impact of liquidity risk on the benefit accrued from electronic banking services in Rafidain Bank and Baghdad Bank.

Hc3: There is a significant impact of liquidity risk on cost reduction of electronic banking services in Rafidain Bank and Baghdad Bank.

\section{Results and Discussion}

Since the present study is considered a comparative study to know the effect between the variables of the study studied, the study relied on achieving its objectives on the descriptive analytical approach. The questionnaire was used to collect data, analyze it, and test hypotheses. SPSS and the Amos pathway analysis program were used as well as many statistical methods such as Cronbach Alpha parameter and mean and standard deviations. It was the result of the stability of the dimensions of the questionnaire, as shown in Table 1. The appropriate value of the Cronbach Alpha coefficient is reasonable in research in management and humanities when its value is (Alpha $\geq 0.70)$ [30]. 
Table 1. Coefficient of internal consistency

\begin{tabular}{||llcc||}
\hline$\#$ & \multicolumn{1}{c}{ variable } & Items & $\begin{array}{c}\text { Cronbach } \\
\text { Alpha }\end{array}$ \\
1 & Banking risk & 18 & 0.907 \\
$1-1$ & Capital risk & 6 & 0.883 \\
$1-2$ & Credit risk & 6 & 0.859 \\
$1-3$ & Liquidity risk & 6 & 0.887 \\
2 & Electronic banking services & 15 & 0.887 \\
$2-1$ & Usability & 5 & 0.812 \\
$2-2$ & The benefit & 5 & 0.838 \\
$2-3$ & Cost reduction & 5 & 0.805 \\
\hline
\end{tabular}

The study population consists of all workers in the Rafidain Bank and the Baghdad Bank in Basra Governorate, Iraq. While the study sample consists of managers, assistants and heads of departments, and at the decision-making site of the Rafidain Bank and the Baghdad Bank in Basra Governorate, Iraq, which were intentionally chosen and numbered 43 individuals, including 25 individuals from the Rafidain Bank and 18 individuals from the Bank of Baghdad. 43 questionnaires were distributed and fully retrieved. Table 2 shows a description of the personal and functional variables of the study sample on individuals.

Table 2. Description of personal and functional variables

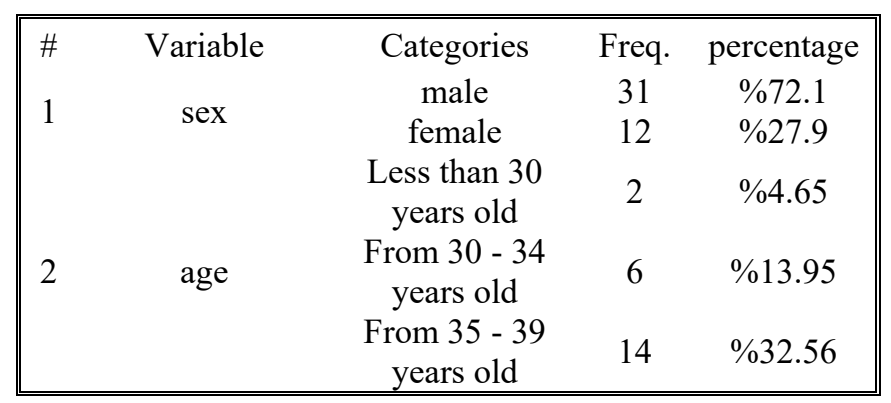

Table 3. Descriptive statistics

\begin{tabular}{||llllllllll||}
\hline \hline$\#$ & variable & \multicolumn{2}{c}{ Rafidain Bank } & \multicolumn{3}{c}{ Baghdad Bank } & \multicolumn{3}{c||}{ difference } \\
& Banking risk & Mean & $\begin{array}{l}\text { Standa } \\
\text { rd dev. }\end{array}$ & Level & Mean & $\begin{array}{c}\text { Standa } \\
\text { rd dev. }\end{array}$ & Level & Chi2 & Sign. \\
$1-1$ & Capital risk & 4.451 & 0.566 & High & 4.472 & 0.556 & High & 2.890 & 0.071 \\
\hline \hline $2-1$ & Credit risk & 4.782 & 0.482 & High & 4.706 & 0.502 & High & 2.532 & 0.063 \\
$3-1$ & Liquidity risk & 4.826 & 0.469 & High & 4.626 & 0.554 & High & 13.083 & 0.000 \\
Banking risks & 4.686 & - & High & 4.601 & - & High & 2.731 & 0.067 \\
$1-2$ & Usability & 4.870 & 0.368 & High & 4.443 & 0.558 & High & 13.310 & 0.000 \\
$2-2$ & The benefit & 4.900 & 0.352 & High & 4.869 & 0.385 & High & 2.738 & 0.069 \\
$3-2$ & Cost reduction & 4.905 & 0.353 & High & 4.760 & 0.492 & High & 17.749 & 0.000 \\
Electronic banking services & 4.891 & - & High & 4.690 & - & High & 14.063 & 0.000 \\
\hline \hline
\end{tabular}

Table 3 shows that the level of banking risks in general came high in the Rafidain Bank, compared to the Bank of Baghdad where the level of banking risks reached a high level as well. The average arithmetic value for banking risks is generally 4.686

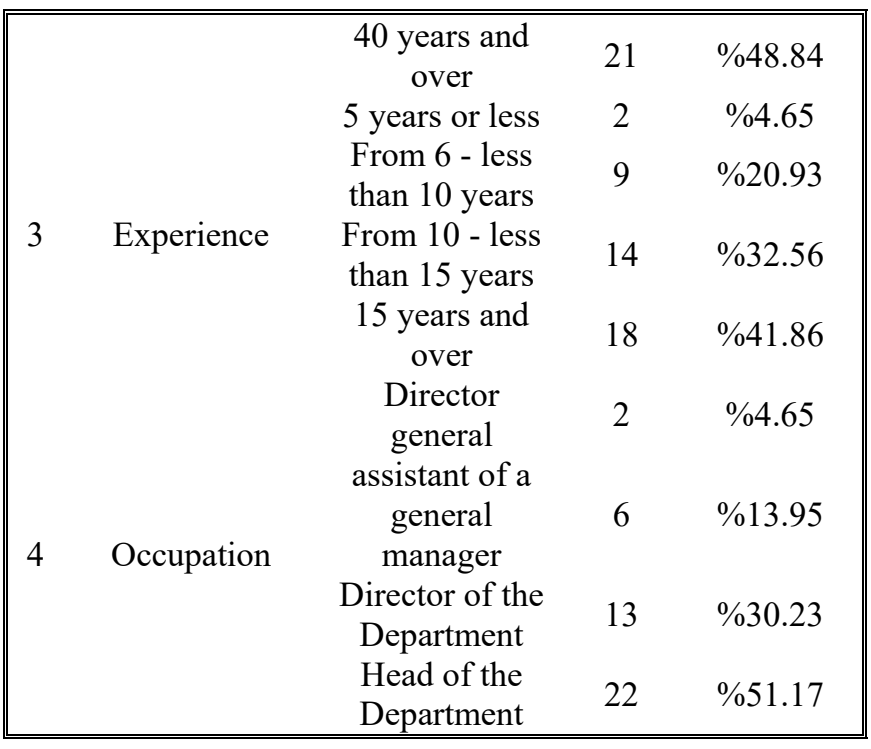

In order to facilitate and discuss the mission of this paragraph, this paragraph has been divided into two parts. The first is specialized in determining the level of study variables, while the second is concerned with testing the study hypothesis. To determine the level of difference in the study variables, the mean value of the paragraph was relied upon by relying on the following relative scale: from degree 1 to less than degree 2.33 the level is low. From grade 2.33 to degree 3.66 the level is average. From the level 3.67 or more, the level is high.

\section{1- Descriptive statistics of study variables}

To describe the level of study variables (banking risks and electronic banking services) in the study sample banks, mathematical averages, standard deviations, level, and coefficient of difference were used, as shown in Table 3. in the Rafidain Bank compared to the average arithmetic value for banking risks in the Bank of Baghdad, which is 4,601. The Table also shows the level of electronic banking services in the Rafidain Bank compared to the Bank of Baghdad. The average 
arithmetic value for electronic banking services in general in the Rafidain Bank is 4,891 and at a high level compared to the average arithmetic value for electronic banking services in the Bank of Baghdad of 4,690 and it is at a high level. The Table also shows the arithmetic averages and the standard deviations for each type of banking risk discussed in the Rafidain and Baghdad banks, in addition to the arithmetic averages and the standard deviations for each dimension of the electronic banking services researched in the Rafidain and Baghdad banks.

Moreover, Table 3 shows that there is no significant difference in banking risks (capital risks and credit risks) between Al-Rafidain Banks and Baghdad, in addition to the absence of a significant difference in the benefit realized from electronic banking services between Al-Rafidain and Baghdad banks. The results also showed that there is a significant difference in liquidity risk between the Rafidain and Baghdad banks, with a value of Chi2 amounted to 13.083 , which is a function at the level of 0.05 , in favour of the Rafidain Bank with an average score of 4,826 compared to the arithmetic mean of the liquidity risk in the Bank of Baghdad, whose value is 4.626. It was also found that there is a significant difference in electronic banking services in general between the Rafidain and Baghdad banks, with a value of Chi2 amounting to 14.063 , which is a function at the level of 0.05 , in favour of the Rafidain Bank with an average score of 4.891 compared to the average of electronic banking services in the Bank of Baghdad. Its value is 4,690. There is a significant difference in the dimensions of usability and cost reduction between the Rafidain and Baghdad banks, with a value of Chi2 amounting to 13.310 and 17.749 , which is a function at the level of 0.05 in favour of the Rafidain Bank with an average score of 4,870 and 4,905 respectively compared to the average arithmetic for usability and cost reduction in the Bank of Baghdad, whose value is 4,443 and 4,760 , respectively.

\section{2- Test the study hypothesis}

To test the study hypotheses, the Structural Equation Model was applied using the Amos program, the twenty-fourth version supported by the SPSS program. This is in order to verify the impact of each type of banking risk on each dimension of electronic banking services in the Rafidain and Baghdad banks, as shown in Table 4.

Table 4 shows the results of the impact of each type of banking risk on each dimension of electronic banking services in Al-Rafidain and Baghdad banks. The results show that there is a statistically significant impact of the capital risks on usability, the benefits and cost maintenance, the rest of which amounted to $0.305,0.200$ and 0.227 , respectively. This indicates the significance of this effect. The value of the impact path (Critical Ratio) of 4.067, 2.857 and 2.873 , respectively, becomes statistically significant at the level of 0.05 . In the same context, the results show that there is a statistically significant impact of credit risk on the usability, the benefit realized, and the cost remaining $0.230,0.415$ and 0.376 , respectively. This indicates the significance of this effect. The value of the impact path (Critical Ratio) of 2.190, 3.772 and 3.836, respectively, is statistically significant at the level of 0.05 . Finally, the results show a statistically significant impact of the liquidity risk on usability, the benefits, and cost maintenance $0.348,0.333$ and 0.348 , respectively. This indicates the significance of this effect. The value of the impact path (Critical Ratio) of 4.296, 4.381 and 4.094, respectively, is statistically significant at the level of 0.05 .

Table 4. Impact test results

\begin{tabular}{|c|c|c|c|c|c|c|}
\hline \multicolumn{3}{|c|}{ Variables } & $\begin{array}{c}\text { Impact } \\
\text { coefficient } \\
\text { values }\end{array}$ & $\begin{array}{c}\text { Standard } \\
\text { error }\end{array}$ & CR & Sig* \\
\hline Capital Risks & $\leftarrow$ & Usability & 0.305 & 0.075 & 4.067 & 0.000 \\
\hline Capital Risks & $\leftarrow$ & Benefits & 0.200 & 0.070 & 2.857 & 0.003 \\
\hline Capital Risks & $\leftarrow$ & Cost Reduction & 0.227 & 0.079 & 2.873 & 0.022 \\
\hline Credit Risks & $\leftarrow$ & Usability & 0.230 & 0.105 & 2.190 & 0.018 \\
\hline Credit Risks & $\leftarrow$ & Benefits & 0.415 & 0.110 & 3.772 & 0.000 \\
\hline Credit Risks & $\leftarrow$ & Cost Reduction & 0.376 & 0.098 & 3.836 & 0.000 \\
\hline Liquidity Risks & $\leftarrow$ & Usability & 0.348 & 0.081 & 4.296 & 0.000 \\
\hline Liquidity Risks & $\leftarrow$ & Benefits & 0.333 & 0.076 & 4.381 & 0.000 \\
\hline Liquidity Risks & $\leftarrow$ & Cost Reduction & 0.348 & 0.085 & 4.094 & 0.000 \\
\hline
\end{tabular}


Moreover, the results of the analysis show that the value of Squared Multiple Correlations is 0.710 for usability, 0.759 for the benefits and 0.735 to cost reduction. Figure 2 shows the effect values between the study variables.

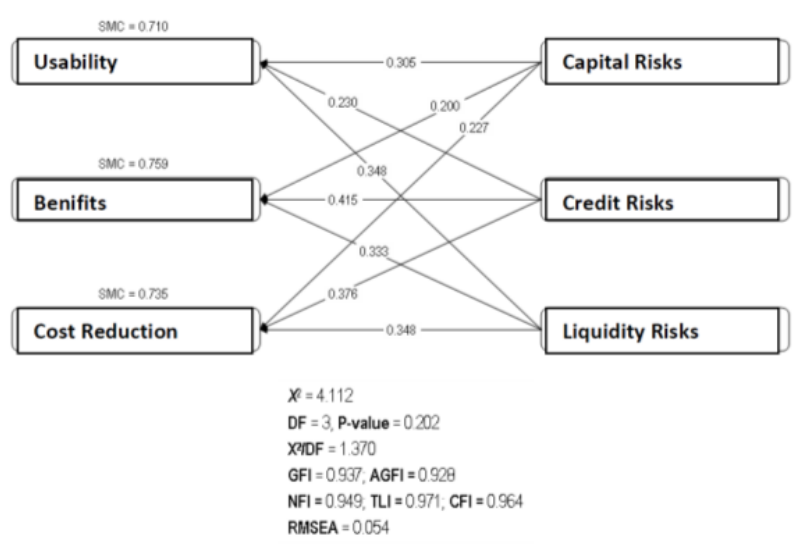

Figure 2. Impact values between study variables

\section{Conclusion}

The results show that the level of banking risks in general is high in the Rafidain Bank compared to the Bank of Baghdad, which reached the level of banking risk at a high level as well. On the other hand the electronic banking services in Rafidain Bank got a high evaluation level compared to the Bank of Baghdad, which also reached a relatively high evaluation level. The results also show that there was no significant difference in banking risks (capital and credit risks) between Rafidain and Baghdad banks, as well as that there was no significant difference in the benefit achieved from electronic banking services between Rafidain and Baghdad banks. Moreover, there is a significant difference in liquidity risk between the Rafidain and Baghdad banks in favour of the Rafidain Bank. There is also a significant difference in electronic banking services in general between the Rafidain Bank and Baghdad in favour of the Rafidain Bank as well. The results of the statistical analysis of the study hypotheses show that there is a statistically significant impact on usability, the benefits and cost reduction. In addition, there is a statistically significant impact of credit risk on the usability, the utility achieved, and cost reduction. There is also a statistically significant impact of liquidity risk on both usability and the benefit achieved by reducing costs. These results require the establishment of mechanisms by banks, the study sample, to help reduce credit risk. These risks are the cause of many banking crises.

It is necessary to keep pace with the banks under study, technological developments in the field of information technology, as well as the use of modern computer hardware and developed software because it has a positive impact on the safety of application and use of information systems. It is also important to spread the culture of modern banking technology and increase the limited specializations for developing technology in the bank. In addition, the technical awareness of customers about the advantages and importance of electronic banking services should be spread through educational programs and brochures using the various media and communication. The capabilities of the study sample banks should be harnessed to provide advanced technical infrastructure, and expand the provision of electronic banking services to include different regions. Finally, it is important for banks to adopt the study sample for legal legislation in the framework of electronic banking transactions that clarify the legal rights and duties of both parties to the transaction. The results of this study are expected to help the banking departments of the study sample in explaining the importance of potential banking risks that can be exposed. Moreover, it sets a set of appropriate strategies to confront the diversity in banking risks and search for ways to avoid them as possible. In addition to this, this study helps in providing information to the authorities related to the most important types of banking risks that banks can direct. On the other hand, this study is one of the few studies that deals with the impact of banking risks on electronic banking services through a comparison between a government bank and a private sector bank. Finally, this study can contribute to opening new horizons for researchers and those interested in current study topics.

\section{References}

[1]. Ali, M. N., Almagtome, A. H., \& Hameedi, K. S. (2019). Impact of accounting earnings quality on the going-concern in the Iraqi tourism firms. African Journal of Hospitality, Tourism and Leisure, 8(5), 112.

[2]. Almagtome, A., \& Abbas, Z. (2020). Value relevance of financial performance measures: An empirical study. International Journal of Psychological Rehabilitation, 24(7), 6777-6791.

[3]. Ali, M., Hameedi, K., \& Almagtome, A. (2019). Does sustainability reporting via accounting information system influence the investment decisions in Iraq. International Journal of Innovation, Creativity and Change, 9(9), 294-312.

[4]. Leo, M., Sharma, S., \& Maddulety, K. (2019). Machine learning in banking risk management: A literature review. Risks, 7(1), 29.

[5]. Tabari, N. A. Y., Ahmadi, M., \& Emami, M. (2013). The effect of liquidity risk on the performance of commercial banks. International Research Journal of Applied and Basic Sciences, 4(6), 1624-1631.

[6]. Lassoued, N., Sassi, H., \& Attia, M. B. R. (2016). The impact of state and foreign ownership on banking risk: Evidence from the MENA countries. Research in International Business and Finance, 36, 167-178. 
[7]. Driouchi, T., So, R. H., \& Trigeorgis, L. (2020). Investor ambiguity, systemic banking risk and economic activity: The case of too-big-to-fail. Journal of Corporate Finance, 62, 101549.

[8]. Culp, C. L., \& Neves, A. M. (2017). Shadow banking, risk transfer, and financial stability. Journal of Applied Corporate Finance, 29(4), 45-64.

[9]. Klomp, J., \& De Haan, J. (2012). Banking risk and regulation: Does one size fit all?. Journal of Banking \& Finance, 36(12), 3197-3212.

[10]. Kostylenko, O., Rodrigues, H. S., \& Torres, D. F. (2017, June). Banking risk as an epidemiological model: An optimal control approach. In Congress of APDIO, the Portuguese Operational Research Society (pp. 165-176). Springer, Cham.

[11]. Apătăchioae, A. (2015). The performance, banking risks and their regulation. Procedia economics and finance, 20, 35-43.

[12]. Almagtome, A., Shaker, A., Al-Fatlawi, Q., \& Bekheet, H. (2019). The Integration between Financial Sustainability and Accountability in Higher Education Institutions: An Exploratory Case Study. International Journal of Innovation, Creativity and Change, 8(2), 202-221.

[13]. Scannella, E., \& Polizzi, S. (2018). Market risk disclosure in banking: an empirical analysis on four global systemically important European banks. Journal of Banking Regulation, 19(2), 87-100.

[14]. Anghelache, C., Anghelache, G. V., Anghel, M. G., \& Nita, G. (2016). General Notions on banking Risks. Romanian Statistical Review Supplement, 64(5), 7-10.

[15]. Pérez-Martín, A., Pérez-Torregrosa, A., \& Vaca, M. (2018). Big Data techniques to measure credit banking risk in home equity loans. Journal of Business Research, 89, 448-454.

[16]. Chen, Y. K., Shen, C. H., Kao, L., \& Yeh, C. Y. (2018). Bank Liquidity Risk and Performance. Review of Pacific Basin Financial Markets and Policies (RPBFMP), 21(01), 1-40.

[17]. Khan, M. S., Scheule, H., \& Wu, E. (2017). Funding liquidity and bank risk taking. Journal of Banking \& Finance, 82, 203-216.

[18]. Witowschi, I. R. B., \& Luca, F. A. (2016). Bank capital, risk and performance in European banking. A case study on seven banking sectors. Prague Economic Papers, 25(2), 127-142.

[19]. Tsintsadze, A., Glonti, V., Oniani, L., \& Ghoghoberidze, T. (2019). Empirical Analysis of Financial and Non-Financial Risks of the Commercial Bank. European Journal of Sustainable Development, 8(2), 101-101.
[20]. Acharya, V. V., \& Schnabl, P. (2010). Do global banks spread global imbalances? Asset-backed commercial paper during the financial crisis of 200709. IMF Economic Review, 58(1), 37-73.

[21]. Al-Wattar, Y. M. A., Almagtome, A. H., \& ALShafeay, K. M. (2019). The role of integrating hotel sustainability reporting practices into an Accounting Information System to enhance Hotel Financial Performance: Evidence from Iraq. African Journal of Hospitality, Tourism and Leisure, 8(5), 1-16.

[22]. Keramati, A., Ghaneei, H., \& Mirmohammadi, S. M. (2016). Developing a prediction model for customer churn from electronic banking services using data mining. Financial Innovation, 2(1), 1-13.

[23]. Arora, S., \& Sandhu, S. (2018). Usage based upon reasons: the case of electronic banking services in India. International Journal of Bank Marketing.

[24]. AlHaliq, H. A., \& AlMuhirat, A. A. (2016). Customer satisfaction with electronic banking services in the Saudi banking sector. Asian Social Science, 12(5), 139-146.

[25]. Hammoud, J., Bizri, R. M., \& El Baba, I. (2018). The impact of e-banking service quality on customer satisfaction: Evidence from the Lebanese banking sector. SAGE Open, 8(3). https://doi.org/10.1177/2158244018790633

[26]. Ho, S. H., \& Ko, Y. Y. (2008). Effects of self-service technology on customer value and customer readiness: The case of Internet banking. Internet Research: Electronic Networking Applications and Policy, 18(4), 427-446.

[27]. Khaghaany, M., Kbelah, S., \& Almagtome, A. (2019). Value relevance of sustainability reporting under an accounting information system: Evidence from the tourism industry. African Journal of Hospitality, Tourism and Leisure, 8, 1-12.

[28]. Calisir, F., \& Gumussoy, C. A. (2008). Internet banking versus other banking channels: Young consumers' view. International journal of information management, 28(3), 215-221.

[29]. Salihu, A., \& Metin, H. (2017). The impact of services, assurance and efficiency in customer satisfaction on electronic banking services offered by banking sector. Journal of Internet Banking and Commerce, 22(3), 1-12.

[30]. Hair, J. F., Sarstedt, M., Matthews, L. M., \& Ringle, C. M. (2016). Identifying and treating unobserved heterogeneity with FIMIX-PLS: part Imethod. European Business Review, 28(1), 63-76. 